\title{
Georgia, the European Union, and the Visa-Free Travel Regime: Between European Identity and Strategic Pragmatism
}

\author{
Chiara Loda* \\ Institute for International Conflict Resolution and Reconstruction, Dublin City University, Dublin, Ireland \\ ${ }^{*}$ Corresponding author. Email: chiara.loda2@mail.dcu.ie
}

\begin{abstract}
In March 2017, Georgian citizens were able to travel visa-free to the Schengen Area. This development was highly significant to Georgia, whose narrative of "belonging to Europe" has long contrasted with the travel restrictions for Georgian citizens, who were previously required to undergo complicated consular procedures. However, this was far from being a routine bilateral negotiation. Visa disparities mirrored the contractual asymmetry between Tbilisi and Brussels. This article focuses on how Georgia calibrated its political discourse vis-à-vis the European Union. After outlining both the symbolic and political relevance of visa liberalization, this work assesses the Georgian political rhetoric at different times: in 2005, when Georgia unilaterally lifted visa requirements for Western visitors, and in 2015 and 2016, when visa liberalization was widely expected. The article's theoretical framework and the final conclusions are relevant to the study of visa regimes and the external relations of small states.
\end{abstract}

Keywords: Georgia; foreign policy; visa diplomacy; small states; visa regimes; strategic narratives

\section{Introduction}

"This is a great achievement. This is a great opportunity for Georgian citizens to better familiarise themselves with the European Union ${ }^{1}$ and the values which the European Union is based on." The Georgian Prime Minister Giorgi Kvirikashvili pronounced this joyful statement on March 28, 2017, the first day Georgian citizens were allowed to travel to the Schengen Area without prior visa formalities. That day Georgian President Giorgi Margvelashvili himself, together with other high-ranking officials, students, journalists, and representatives of ethnic minorities, celebrated the event by flying to Athens, Greece (Papidze 2017). That celebratory flight came after five years of negotiations, regulatory adjustments, and delays. In 2012, the visa liberalization dialogue started and, in December 2015, the European Union (EU) Commission stated that Georgia met the necessary conditions (European Commission 2015). However, the EU member states gave the green light to visa liberalization only in October 2016, after the introduction of the suspension mechanism, which allowed the EU Commission to temporary reintroduce visa requirements, up to a maximum of 27 months, in exceptional circumstances, such as high rates of overstaying and scarce cooperation in readmission procedures (Grigalashvili 2016). Far from being a mere technical matter, there

\footnotetext{
${ }^{1}$ Even though this article, mirroring the mainstream narrative, often uses the term "visa-free regime within the European Union (EU)," what is actually discussed is a visa-free regime within the Schengen Area. Notably, as of June 2017, Georgians transiting through Ireland need to secure a transit visa prior their journey (Irish Statute Book 2017).
} 
was an apparent contrast between Georgian policymakers pledging allegiance to Europe and the restrictions in mobility for Georgian citizens.

Building upon the literature of extra-European small states, this work considers these asymmetric travel regimes to be related to the size inequality between the small state of Georgia and the EU. In this regard, the rhetorical choices made by Tbilisi can be read as an attempt to navigate the situation. As this work shows in detail, although Georgian policymakers constantly emphasized the Europeanness of the country, over time the intensification of the cooperation with the EU has been accompanied by a more strategic use of political discourse. ${ }^{2}$ This analysis brings about a micro-meso-macro contribution. At the micro level, it provides evidence for the underinvestigated case of visa policies in Georgia, showing that they involve both practical and symbolic elements. Similar aspects have been analyzed in the case of Ukraine (Sasse 2017, 2016), whose visa liberalization process followed a similar trajectory, but no equivalent attention has been payed to the Georgian experience. At the meso level, it contributes to the current limited literature on travel regimes, showing how visa regimes can simultaneously show openness, mirror bilateral disparities, and be related to national status. At the macro level, it contributes to the understanding of the asymmetrical relationship between great and small powers, showing that political rhetoric tends to adjust to that.

\section{The Interaction of Georgia and the EU under Asymmetry: Some Thoughts on Smallness in International Relations}

Unequal travel provisions in place between Georgia and the Schengen Area, amended only in March 2017, mirrored the size disparity between these two uneven actors. Rather than being a peculiar dynamic, this kind of inequality represents a crucial element in the relationship between small and great international actors. Robert Steinmetz and Anders Wivel (2010) define small states as "the weak part in an asymmetric relationship" (6). This definition is particularly relevant for extra-European states, as their EU counterparts hugely benefit from Brussels' collective decision-making style. After gaining independence from the Soviet Union and joining both NATO and the EU in 2004, the Baltics are a remarkable example of such empowerment. In contrast, Georgia, who remains a simple neighbor of the EU, did not escape from these dynamics of asymmetry (Wivel 2016). Paraphrasing Orwell, Wivel (2016) states that "all small states are equal but some small states are more equal than others" (104).

Although some inequality is expected to play into a large number of situations in the realm of international relations, it is particularly illustrative in visa regimes. Remarkably, unreciprocated visa regimes may have the function to mirror inequalities between wealthy and developing countries (Helleiner 2015; Neumayer 2006, 2010). Indeed, although most visa-free regimes are negotiated as reciprocal acts, this does not apply to the prosperous Organisation for Economic Co-operation and Development (OECD) countries, whose citizens face much fewer travel restrictions than their nonOECD peers (Neumayer 2006). In other words, affluent countries are often able to secure favorable travel regimes for their citizens without returning an equal benefit to their poorer counterparts. Studying how visa regimes have evolved from 1969 to 2010, Steffen Mau and colleagues (2015) noticed that although the free mobility for citizens of the OECD countries increased, citizens of nonaffluent countries were mostly excluded from it. In addition to these economic considerations, the perception of cultural compatibility appears to be positively related to the lifting of visa requirements (Helleiner 2015, Neumayer 2010). In this regard, Claudia Finotelli and Giuseppe Sciortino (2013) observed that the visa requirement imposed on poor Asian and African countries

\footnotetext{
${ }^{2}$ Notably, Georgia was included first in the European Neighbourhood Policy (ENP) in 2004 and then in the Eastern partnership (EaP) in 2009. The Association Agreement was signed in 2014. The UNM party lost its parliamentarian to the Georgian Dream in 2012. Even though there may be a correlation between all of these events and the increased assertiveness in the political discourse, this article does not discuss it. In other words, the focus is on how the political rhetoric evolved, not why it happened.
} 
by EU member states were more severe that those imposed on Eastern European countries with developing economies and oil-rich economies. Similarly, Mau (2010) agrees that travel regimes are not purely a consequence of political and economic situations, as demonstrated by the fact that most black-majority or Islamic-majority countries are excluded from visa-free regimes. However, although the non-EU East European countries are better positioned than others in terms of travel conditions to the West, the relationship is far from being symmetrical. That is also inferable from the fact that, discussing the tools of the Eastern Partnership (EaP), free mobility to the EU is often conceptualized as a carrot (Börzel 2016, Ademmer and Delcour 2016, Ademmer 2012, Grant 2011). This expression, together with other terms such as "fortress Europe," frames the very act of travelling to the West as a privilege cherished by foreign citizens.

As this section illustrates, the analysis of visa inequalities mostly concerns the perspective and the discourse of Western states and organizations. Conversely, no comparable attention is paid to the agency of small extra-European states. In the attempt to fill this gap, this work analyzes the political rhetoric of small states. Small states, when addressing greater counterparts, tend to adjust their public discourse to the assumed preferences of their external audience (Loda 2017). For example, Azerbaijan, whose well-funded public diplomacy strategy primarily targeted the West, promoted an ad hoc narrative of multiculturalism and religious coexistence (Loda 2016). In addition to attributing meaning to public declarations, something can be inferred from their absence. For instance, the silence of the Armenian government against Russia selling weapons to Azerbaijan does not have to be interpreted as a casual omission, but rather as a feature of the highly unbalanced relationship between Moscow and Yerevan. ${ }^{3}$ Generalizing this example, it is here argued that, in addition to adjusting their rhetoric to the peculiarities of their external audience, small states may resort to silence as a tool to avoid or de-escalate tensions. Throughout this work, these conscious discursive omissions, made by small states vis-à-vis greater counterparts, are referred to as "unvoiced asymmetry."

\section{Visa Regimes, Foreign Policy, and Small States}

In addition to being related to global inequalities, visa regimes and policies can signal other things, such as the quality of the different bilateral relations and the general attitude of a country vis-à-vis the external environment. Additionally, they can have implications on the perception of national status and identity. Given the surprising underinvestigation of this topic (Neumayer 2006), and before dealing specifically with the Georgian case, some possible implications of travel and visa policies will be reviewed.

First, the relaxation of admission requirements can be related to a state's degree of openness. For example, autocratic regimes are often suspicious of foreign influences and, therefore, prone to putting in place visa restrictions (Neumayer 2010, 178). In 1999, the withdrawal of Turkmenistan from the Commonwealth of Independent States (CIS) visa-free regime signaled the limited interest on the part of Ashgabat in interacting with the outside world (Pomfret 2008). By contrast, Turkey's visa system can be interpreted as a soft power tool of the country (Kirişçi and Kaptanoğlu 2011, Kirişçi 2005) and as a tangible sign of its multi-vector foreign policy (Devrim and Soler 2010). More precisely, abolishing visa requirements for neighboring countries such as Egypt, Lebanon, and Iran has fostered the interactions between Ankara and these countries. However, these choices, which increased the activism of Turkish civic organizations and business organizations in the region (Öner 2013), have hampered the visa liberalization process with the EU, ${ }^{4}$ as Brussels feared a flux of illegal migrants transiting through Turkey (Özler 2012). Second,

\footnotetext{
${ }^{3}$ For a more detailed account, refer to Mirzoyan (2010).

${ }^{4}$ The rationale behind these choices could be hypothesized to be in line with Senem Aydın-Düzgit's (2016) observations about Turkey progressively distancing itself from Europe and, conversely, focusing more on the Middle East and North Africa.
} 
certain travel regimes are the direct product of international tensions. In addition to refusing the admission of Israeli citizens, most Middle Eastern countries deny entrance to foreign nationals with an Israeli entrance stamp on their passport. In November 2015, as a consequence of Turkey shooting down a Russian jet, the Kremlin unilaterally reintroduced visa requirements for Turkish citizens (Bertrand 2015). Furthermore, visa policies may factor into quarrels on territorial integrity. Notably, between 2008 and 2012, the Kremlin was furious with the Georgian decision to exempt North Caucasians only from visa requirements, making a de facto differentiation among Russian citizens (Umodov 2010). Similarly, in 2010, the Chinese decision to give stapled visas, instead of stamping their passports, to Indian citizens from Jammu, Kashmir, and Arunachal Pradesh was interpreted by India as an expedient to question its territorial integrity (Paul and Shankar 2014, 181). Third, a liberal migration regime can be a mechanism of attraction toward smaller states. For instance, granting a visafree regime to most post-Soviet countries is a component of the "soft-power portfolio" of Russia (Popescu and Wilson 2009, Wilson and Popescu 2009). Fourth, there is a link between travel regimes and perception of national status, as visa regimes marks the difference between desirable visitors by default and potentially undesirable ones (Neumayer 2006). As said by Stef Jansen (2009), the "relations between different passports are hierarchical and (...) they are experienced as such" (817). Reflecting on the link between individual regime mobility and perception of the Self, Salter (2006) uses the term "biopolitical" to indicate how visa regimes influence how "we understand ourselves as mobile bodies" (168). Ultimately, these elements have an effect on the grassroots self-perception of national status. Studies on the post-Yugoslavia case show how citizens of the newly independent states, not able to travel visa-free anymore to most EU countries, perceived this new regulation as downgrading their Europeanness (Jansen 2009). On the other hand, being exempted from visa requirements can be perceived as an upgrade of the national status. Ha-Joon Chang (2007), remembering the rampant years of the economic growth in his native South Korea, writes that "[i]n the late 1980s, Korea had become a solid uppermiddle-income country. The surest proof of this was that European countries stopped demanding that Koreans get an entry visa" (xviii).

While these considerations are relevant for most developing countries, the Georgian case stands out as crucial due to the contrast between voiced Europeanness and limited mobility. As the next section illustrates, the Georgian political discourse has consistently emphasized the European identity both of the country and its citizens. Notably, declarations like "European choice of the country is not only the aspiration of political groups or the government, but it is also a choice of Georgian people" (President of Georgia 2015) seem to overlook the fact that, until recent times, Georgians were required to fill out a visa application before every single trip to the Schengen area. ${ }^{5}$ Even more so, there is some contrast between the slow pace of the visa liberalization negotiations and the almost absence of open complaints in the Georgian political discourse. In light of the concept of "unvoiced asymmetry," it is hypothesized that verbal moderation stems from the awareness of the asymmetry between Tbilisi and Brussels.

\section{Georgia: A European Country by Destiny and by Choice}

The importance of the visa-free regime with the EU is not only due to practical reasons. In fact, freedom of mobility represents a concrete way to reaffirm Georgia's "Europeanness." A distinctive trait of the Georgian political narrative is that it depicts this "aspiration to the West" not only in terms of institutional or market cooperation, but also in terms of returning the Georgian people to their European dimension. In 1999, the Georgian Prime Minister Zurab Zhvania, addressing the Council of Europe, articulated the famous sentence: "I'm Georgian, and therefore

\footnotetext{
${ }^{5}$ Long-term Schengen visas were not commonly granted. Additionally, there was no clear procedure to obtain them (personal communication to the author, Spring 2015, Tbilisi).
} 
I am European" (Kakachia and Minesashvili 2015, 174). During his presidency, Saakashvili insisted that Georgians were Europeans both by nature and by choice. For instance, he remarked on the Europeanness of Georgians by referring to scientific elements: "Georgia is one of the European states. It is proved by the fact that the skulls of the oldest Europeans, the Georgians, are kept in the museum, which is a 200-meter walk from here" (Saakashvili 2006a). Additionally, throughout his period of power, he was consistent in saying that the Rose Revolution represented a Western choice and, by extension, a choice not to be anything other than Western. The year after the Rose Revolution, he spoke about the need of renovating the transport system by saying that: "We will bring in hundreds more buses, so that we have normal, European, civilized transport, not like Bombay. (...) if we are a European country, we cannot be like some Asian or African city. We should have European looking towns and villages" (Saakashvili 2005a). In a nutshell, it has been observed that self-perception as Europeans, often framed as "return to Europe," is a strong component of the Georgian identity (Kakachia and Minesashvili 2015, German 2015, Ó Beacháin and Coene 2014), which guides not only the domestic policies but also the foreign policy choices (Kakachia and Minesashvili 2015). Pertinently, to suggest the natural belonging of Georgia to Europe, the United National Movement (UNM) put considerable discursive emphasis on Georgia being a Black Sea country (Kakhishvili 2016, 172). In 2006, in occasion of the Munich Security Conference, President Saakashvili described Georgia as a Black Sea country, like Romania and Bulgaria, yet to be fully included in the European integration process (Brisku 2013, 193).

Notwithstanding its broad articulation, this strong identity component is not free of contradictions. For example, the constant claims of a European identity often seem to be in contrast with the adoption of politics more in line with the US ones, like market deregulation and privatization of services such as healthcare (Ó Beacháin and Coene 2014, Cheterian 2008, Lazarus 2013). Additionally, it has often been mentioned how Georgian politicians sometimes declared that Singapore, a prosperous and authoritarian microstate, could be the exact model of development for Georgia (Ó Beacháin and Coene 2014, Papava 2014, Delcour 2013, Papava 2013). More generally, some contrast has been noticed between the voicing of European aspirations and the delay in adopting those EU regulations not in line with the domestic agenda (Delcour and Wolczuk 2015, Ademmer and Börzel 2013, De Waal 2011). Despite these contradictions, visa simplification with the EU has steadily been pursued as a goal. Even though some declarations about the "Georgian Europeanness" are allegedly distant from grassroots concerns, surveys show the importance attributed to this issue by ordinary citizens. For example, in 2015, 77\% of respondents expected the EU Association Agreement to be followed by a simplification of visa procedures (CRRC 2015). Similarly, in June 2016, when the visa-free regime with the EU seemed imminent, $64 \%$ of respondents declared to expect some tangible benefit to result from that provision (CRRC 2016). These answers are not surprising to anyone familiar with the Georgian middle class and its rumors, until March 2017, about the strictness of the different Schengen embassies. ${ }^{6}$

The Georgian emphasis on portraying itself as a European country suggests that achieving a visa-free regime came with the consequences of not only being practical, but also symbolical. As emerge from interviews and some knowledge of the Georgian context, visa liberalization simplified, as opposed to revolutionized, the life of most Georgian tourists. ${ }^{7}$ On the other hand, this provision had a high symbolic meaning: showing to ordinary citizens the willingness of the "European community" to acknowledge them as peers. ${ }^{8}$

\footnotetext{
${ }^{6}$ The author lived and worked in Tbilisi for most of 2015. At that time, she participated in numerous conversations of this kind.

${ }^{7}$ The visa-free regime applies only to short-term visitors.

${ }^{8}$ Interview to Eastern European Diplomat, September 28, 2016, Tbilisi.
} 


\section{Georgia and Visa-Free Regime: A Consistently Nonconfrontational Discourse}

An examination of the political discourse reveals that visa simplification and visa liberalization have consistently been a declared goal of both President Saakashvili and President Margvelashvili. ${ }^{9}$ Despite the time passing and the changes in power, moderation and avoidance of maximalist requests seem the main guiding principles of the elites in Tbilisi. In other words, while free traveling has been consistently depicted as a desirable outcome, the rhetoric tended to be articulated in terms of desire rather than demands. Throughout this section, the features related first to the UNM government and then to the Georgian Dream government will be discussed.

Even though at the beginning of the Saakashvili administration visa-free regime was mere wishful thinking, political elites did not hide their interest in this eventual goal. In 2007, President Saakashvili (2007a) announced that soon the long lines outside embassies would be only a memory as Georgians citizens were about to be granted a visa facilitation program (the agreement was eventually implemented in 2010). In 2009, he reported enthusiastically that, during the NATO summit in Brussels, it was mentioned for the first time the possibility to grant a visa-free regime to Georgia (Saakashvili 2009a). In the same year, when the visa facilitation regime was about to enter into force, he declared, "We are on the last stage of signing an agreement regarding the visa regime. (...) This is the first serious signal sent by EU after the Russian aggression" (Saakashvili 2009b). A first visible result of that would be "that people will not have to stand in long lines" (Saakashvili 2010). This was not the first reference of Saakashvili to a highly visible symbol. On another occasion, referring to the talks on the visa liberalization process, he argued, "Each citizen of Georgia must be able to cross over to the European Union territory with an ordinary passport." This mix of logistic and symbolic implications of visa regimes is in line with other studies. Jansen (2009), in his study of Bosnia and Herzegovina, observed that the lines outside the embassies symbolized the hierarchical disparities between the embassies of the EU countries, protected by guards and high fences, and local applicants, waiting in line for their turn to enter. Therefore, although the EU is never openly accused being unfair toward Georgian citizens, it emerges that Georgians political elites, in addition to describing their people as unequivocally European, framed the prospect of enhanced mobility as a crucial upgrade of their Western status. The following quote further reinforces this point: "We are one step away from having our citizens travel to Europe visa-free with their Georgian passports, carry all of our products custom free and feel like full members of Europe and participants of its processes" (President of Georgia 2012).

Even though the Georgian Dream government, which has been in power since 2012, has often been said to be less pro-European than its predecessor, President Margvelashvili has not only been consistent in advocating for the visa-free regime, but also eager to take all the necessary steps to obtain this. More specifically, since 2012, Georgia has agreed to ratify seven international conventions and to adopt eight national strategies, around 60 legislative amendments and roughly 70 bylaws, regulations, and instructions (Moody 2016). Through 2015 and 2016, when visa liberalization seemed imminent (and Georgia got regularly disappointed by the delays ${ }^{10}$ ), the president often mentioned the commitment of the country to that goal. Notably, it was often pointed out that enhanced mobility would favor the Georgian European integration. Additionally, it has been indirectly said that the visa-free regime would endorse Georgia as a frontrunner in the Eastern Partnership. For instance, President Margvelashvili (2016) declared, "We believe that granting Georgia with the short-term visa-free travel regime will be an encouraging model for other EU partner countries, demonstrating that reforms are feasible and states are promoted in line with the 'more for more' principle." However, in line with the broad Georgian narrative, political elites refrained from any articulated criticism both toward the EU and specific

\footnotetext{
${ }^{9}$ Due to space and scope limitations, this paper mostly focuses on the political discourse. For a detailed account of the media discourse on visa liberalization, refer to Tsuladze et al. (2016).

${ }^{10}$ Private communication to the author, Spring 2015, Tbilisi.
} 
"EU prominent actors." Remarkably, while comments like "We are trying to make it understood that visa liberalisation for Georgia is not, in any way, connected to the migration crisis" (BBC Monitoring Trans Caucasus Unit 2016a) seemed in direct response to the perplexities of Berlin and Paris, nevertheless no reference was made to specific countries.

Even though some discursive moderation provides an element of continuity, some change in the strategic approach of Tbilisi toward Brussels can be noted over time. ${ }^{11}$ The next two sections will illustrate that, while at the beginning of the Saakashvili's presidency visa discourse mostly centered on signaling openness, a decade after political elites tried to frame visa liberalization as fully consistent with Brussels' objectives (and, by extent, not as a unilateral favor to Georgia). More specifically, it will be offered a detailed account of the Georgian rhetoric concerning two crucial happenings: the sudden simplification of the travel regime to Georgia in 2005, and the months preceding the decision on visa liberalization for Georgia in 2015 and in 2016.

\section{Georgia and Visa Regimes: Signaling Openness}

In 2005, less than two years after the "Rose Revolution," Georgia granted visa-free traveling to the citizens of most OECD countries. Considering the precarious situation of Georgia at the time, that move represented a unilateral goodwill gesture. This section argues that, with reference to the concept of "unvoiced asymmetry," some uneasiness can be tracked down by looking at discursive omissions.

Since June 2005, Georgia has implemented an incredibly generous visa policy that allows citizens from 31 developed countries to get at the airport a visa valid for 90 days (AP World Stream 2005). In 2009, the visa-free period had been extended to 360 days. Additionally, throughout the years, the list of visa-free countries has kept expanding (Gabrichidze 2011). While in 2014 the maximum visa-free stay was amended back to 90 days (Tabula 2014), the following year the 360 days rule was restored ${ }^{12}$ (Agenda.ge 2015). Back in 2005 this choice, which was in line with the other liberal policies of the Saakashvili administration, could be explained in light of the desire to attract foreigners (both travelers and investors). ${ }^{13}$ By this logic, even if entirely unreciprocated, an open visa-free regime was central to the interest of the country, which at the time was extremely poor and with an undeveloped electrical system. As pointed out by a Western European diplomat, opening up was by far the best choice for Georgia. ${ }^{14}$

Notwithstanding these advantages, the choice to unilaterally liberalize the visa regime clearly reflected the size disparities between the small Georgia, desperate for foreign investments, and the affluent OECD countries. Acknowledging the limits of counterfactual arguments, ${ }^{15}$ thus this

\footnotetext{
${ }^{11}$ Providing an account of the mechanisms related to this transition goes beyond the possibilities of this article.

${ }^{12}$ It is matter of debate to what extent these choices were influenced by external preferences and recommendations. In the previous years, the international organization for migration (IOM) expressed some concern for Tbilisi's extremely liberal migration policy. In fact, in 2008, an IOM report highlighted some potential unintended consequences, such as irregular migration flows and international crime. In summer 2014, the then Foreign Minister Maia Panjikidze commented the forthcoming amendments to the immigration law, emphasizing their consistency with the Visa Liberalization Action Plan (Yundt 2014). However, EU officials stressed that these amendments were not the result of specific requests. In October 2014, former EU Commissioner for Home Affairs, Cecilia Malmström argued that the EU Commission "has not been recommending limiting access to Georgia for citizens of any specific countries." A similar point was made by Janos Herman, EU Ambassador to Georgia. The introduction and implementation of the new immigration rules, highly unpopular with the expat business community, were highly criticized due to the ambiguity of requirements and procedures (Ellena 2015). After less than one year, the government responded by restoring a liberal travel regime.

${ }^{13}$ Interview with Timothy Blauvelt, September 25, 2016, Tbilisi.

${ }^{14}$ Interview with "West European Diplomat 1," September 26, 2016, Tbilisi.

${ }^{15}$ As pointed out by Sagan (1996), no certain conclusions can be made out of counterfactual arguments. In this specific case, the limited material available further complicates the task.
} 
article hypothesizes some distress, on the part of Georgia, with this highly asymmetric arrangement. That is inferred from the lack of public declarations about this unilateral concession, which is here interpreted a conscious choice. More in details, it is remarkable that President Saakashvili, on other occasions extremely vocal about the opening of the country, did not include this revolutionary move in any of his speeches. In line with that, members of Parliament and ministers refrained from discussing it. ${ }^{16}$ Agence France Press (2005), one of the few agencies reporting the event, reported only Goga Chkhenkeli, a functionary from the Georgian international tourism department, saying that, "the president believes we should do everything to boost Georgia's popularity in the world." However, there is no firsthand record of (the usually vociferous) Saakashvili endorsing this move, despite previous declarations about the importance of developing the country through the promotion of tourism. For example, even if only one week before President Saakashvili had commented on how the renovation of the Old City of Tbilisi would prompt tourism (President of Georgia 2005), yet he refrained from making any comment about the draft bill on visa liberalization. In brief, even though no certain conclusions can be drawn from the absence of political declarations, contextualizing them into the broader political narrative seems to highlight some uneasiness with the unilateral ${ }^{17}$ nature of this policy.

This argument about the Georgian political elites trying to downplay the power asymmetries related to visa regimes is further reinforced when compared to the rhetorical emphasis put on the establishment of a mutual visa-free regime ${ }^{18}$ with Turkey. Such agreement was signed in Tbilisi, in March 2006, on the occasion of the visit of the Turkish Prime Minister Recep Tayyip Erdoğan. In that circumstance, President Saakashvili did not limit himself to saying that the new provisions would enhance trade and tourism. Remarkably, he associated this event to the overcoming of the Soviet past: "Georgian-Turkish border, which was one of the most closed borders during the cold war (.....). This [agreement] will enter the history as the most successful fact in terms of the development of bilateral relations and the whole region" (Saakashvili 2006b). Far from this being an isolated quote, it was successively restated that the new travel regime represented a net departure from less than a decade before, when an open border between the Soviet Union and a NATO country had been simply unthinkable (Saakashvili 2006c). According to Mr. Saakashvili, this departure from the past was facilitated by Turkey, which, as a consequence of a visa-free regime and a free-trade regime, acted as "a window into Europe, the rest of the world and a better future" (BBC Monitoring Former Soviet Union 2006). In general, freedom of mobility was presented as a favorable effect of the transition, as shown by the following presidential declaration: "It has become necessary to have a 48-page thick passport. We don't live in Soviet times when people could go abroad only twice a year" (Saakashvili 2006d).

Recapitulating, there is a striking contrast between the emphasis given to the mutual liberalization of the visa-free regime with Ankara and the silence about the unilateral visa liberalization accorded to most Western countries. Interpreting these discursive omissions in light of a broader framework of "unvoiced asymmetry," they seem to suggest that although the Georgian elites were aware of the necessity of opening up the country and eager to get closer to Western actors, some uneasiness with that asymmetry could be detected.

\footnotetext{
${ }^{16}$ In this aftermath of this visa liberation, the Georgian lawmaker Kote Gabashvili pointed out the difficulty for Georgians to obtain visas to foreign countries. However, it mostly remained a singular comment (Agence France Press 2005).

${ }^{17}$ Even though the chapter focuses on visa policy, it is not the only case of "unvoiced asymmetry." The massive voluntary contribution of troops in Iraq, impressive for a non-NATO member, is also a sign of that.

${ }^{18}$ As from 2004, citizens of most Soviet countries (with the exception of Kazakhstan, Kirgizstan, and Uzbekistan) were able to enter to Turkey only with a broader-issued visa, usually valid for one or two months. The only exception was Georgia, whose citizens were granted a 15-day-long visa. During the following years, Turkey consistently pursued an open visa policy (Kirisci 2005).
} 


\section{Territorial integrity and Pro-Western Orientation: The (Voiced) Role of Visa Liberalization}

In 2012, the visa liberalization dialogue between Tbilisi and Brussels started. By the end of $2014,{ }^{19}$ that achievement seemed forthcoming. However, the formal decision was only announced in October 2016 and implemented in March 2017. Although the Georgian political rhetoric remained clearly nonconfrontational, there is a departure from the "unvoiced asymmetry" style of 2005. A decade after, Georgian elites were able to make a more strategic use of political discourse, as inferable from the arguments brought forward to advance the process of visa liberalization. Thus, even though proper requests were avoided, it was often emphasized that granting the visa liberalization regime to Georgia would have advanced two goals, also supported by the EU: territorial reintegration and marginalization of pro-Russian parties.

When looking at the political rhetoric in the months and years preceding the free-travel agreement, it was often pointed out that granting visa liberalization to Georgia could promote territorial reintegration. The core argument was the following: should Georgia be granted a visafree regime with the EU, citizens of Abkhazia and South Ossetia would have a strong incentive to apply for a Georgian passport. Eventually, and despite the Russian preferences, this grassroots pragmatism would lead to the reunification of the country. Additionally, according to this narrative, visa liberalization would be a response to some "neutral parties," which link territorial reintegration to the support of Russia and a message to the citizens of Abkhazia and South Ossetia about the new attraction-based reintegration policy. In 2013, on the occasion of the Eastern Partnership summit, which resulted in the initiation of the Association Agreement between Georgia and the EU, President Margvelashvili declared, "Association is the key to peaceful reconciliation with our compatriots in occupied Abkhazia and Tskinvali Region and the reunification of our country, because it is by ATTRACTION that we will draw these regions back into the Georgian state" (Margvelashvili 2013 [capitalization in the original document]). Reflecting on concrete terms what attraction for Europe could be constituted by, visa facilitation has frequently been mentioned. ${ }^{20}$ Paata Zakareishvili, the Georgian Minister of State for Reconciliation and Civic Equality, recalling the pragmatic approach of South Ossetians receiving healthcare ${ }^{21}$ in Georgia and mentioning the success stories of North Cyprus and Transnistria, argued that "visa liberalisation gives them an amazing opportunity to travel to Europe easily with just one passport. This means a lot to them" (BBC Monitoring Trans Caucasus Unit 2016b). The reasons for this are the following. Even though, as early as in 2005, 80\% of Abkhazians were estimated to have a Russian passport (BBC Monitoring Former Soviet Union 2005), European consulates were often unwilling to issue them a visa. Due to these travel limitations, citizens of Abkhazia and South Ossetia would have an incentive to apply for a Georgian passport, which would allow them to travel to the EU without consular formalities. Dragging some parallelism, a similar dynamic has been observed in the case of Transnistria and North Cyprus where, as a consequence in one case the free-travel regime with the EU and in the other case of EU membership, passport requests to the base-state sharply increased (Tsurtsumia-Zurabashvili 2016).

In spite of the validity of these arguments, other elements suggested that, in the particular case of Georgia, the visa free regime would have a limited impact on territorial reintegration. First,

\footnotetext{
${ }^{19}$ Private conversation with EU functioner, Brussels, December 2014.

${ }^{20}$ Ironically, this argument was originally mentioned while discussing a possible visa-free regime between the EU and Russia. On that occasion, some concern was raised about the potential impact of this move over the territorial integrity of Georgia (Golunov 2011).

${ }^{21}$ In spite of the absence of a public health system in Georgia, the Georgian government subsidizes the medical treatments of citizens of Abkhazia and South Ossetia. Although during the Saakashvili administration this benefit was conditioned to the acquisition of Georgian documents, the Georgian Dream administration lifted this requirement. As of 2015, several hundreds of South Ossetians had traveled to Georgia for medical reasons (Menabde 2015).
} 
citizens of Abkhazia and South Ossetia faced social and legal pressure to refuse Georgian travel documents. Indeed, the authorities of the de facto entities legislated against initiatives in this direction. For instance, the president of Abkhazia announced the intention to expel those international organizations that offer neutral Georgian travel documents to Abkhazians (Caspersen 2015, 402). Additionally, between 2015 and 2016, both Sukhumi and Tskhinvali passed Laws on Foreign Citizens detrimental of the civic and property rights of dual citizens. ${ }^{22}$ Social pressure also factors into the equation. In summer 2015, some young Abkhazians went to Tbilisi because of a "UEFA Super Cup" football match. The Abkhazian press promptly criticized it as an antipatriotic act, making statements like "It wasn't worth to disregard the enormous sacrifices, which our nation suffered, in order to see [the football player] Lionel Messi" (Cagara 2015). The current situation is that most citizens of de facto states refuse to accept neutral travel documents (i.e., without reference to nationality) issued by Georgia. ${ }^{23}$ Considering this hardline scenario, visa liberalization on its own and not supplemented by economic benefits or scholarship opportunities attached hardly seems like a game changer. ${ }^{24}$ This issue is further complicated by the nonexclusively ethnic nature of the conflict. In fact, in addition to the people level, the Russo-Georgia dimension and the Russo-West dimension also must be considered, ${ }^{25}$ and although the visa-free regime could persuade some people to request a Georgian passport, the overall size of the phenomenon is likely to be limited. Additionally, were Georgia granted a visa-free regime with the EU, experts expected Russia to offer a deeper form of cooperation to Abkhazia and South Ossetia. ${ }^{26}$ Considering all these different arguments, the discursive emphasis between visa liberalization and territorial reintegration can be interpreted as an indirect invitation to the EU to live up its pledge to the territorial integrity of Georgia. ${ }^{27}$

In addition to sending a message to the Western audience, connecting visa liberalization and territorial reunification could have another aim: contrasting the pro-Russian version, proposed not only by Russia itself but also by Georgian "neutral parties," which sustains that only some support from Moscow would make territorial reintegration possible. This position is predominant in the Russian narrative. For example, the Russian journalist Marina Perevozkina wrote that, as consequence of Georgia integrating with Europe, Abkhazia and South Ossetia were reinforcing their ties with Russia and thus making irreversible their separation from the parent state (BBC Monitoring Former Soviet Union 2013). This point seems also shared by the so-call pro-Russian segment of the Georgian political debate, ${ }^{28}$ which agrees on saying that that territorial reintegration cannot happen without an active intervention of the Kremlin (Kakhishvili 2016, 180-181). Recapitulating, while for the time being a visa-free regime could only have a marginal effect on the reunification of Georgia, a discursive emphasis of that is functional both toward a domestic and an international audience.

Yet, with reference to visa liberalization, "neutral parties" were not only framed as political contenders but were also used as an instrument of leverage over Brussels. Notably, in occasion of the electoral campaign in 2016, signed by the resurgence of allegedly pro-Russian parties, ${ }^{29}$ Georgian political cadres often pointed out how these actors could be further empowered by more delays in granting Georgia the visa-free regime. Even if this claim was not totally groundless, this work argues that overemphasis was intentionally places in political speeches to

\footnotetext{
${ }^{22}$ Interview with EU Officer, September 29, 2016, Tbilisi.

${ }^{23}$ Interview with Levan Kakhishvili, September 27, 2016, Tbilisi; Interview with Bakur Kvashilava, September 30, 2016, Tbilisi.

${ }^{24}$ Interview with Kornely Kakachia, October 1, 2016, Tbilisi

${ }^{25}$ Interview with EU Officer, September 29, 2016, Tbilisi.

${ }^{26}$ Interview with EU Officer, September 29, 2016, Tbilisi.

${ }^{27}$ See, for example, European Union External Action (2015).

${ }^{28}$ Due to the pro-Western nature of the Georgian political landscape, no party has an open pro-Russia agenda. However, some "pro-Russian elements" emerge from the political discourse (Kakhishvil 2016, 176-177).

${ }^{29}$ In October 2016, the neutral party "Alliance of Patriots" had six of its members elected in the national parliament.
} 
instill some urgency in decision-makers in Brussels. Over the months, Prime Minister Giorgi Kvirikashvili repeatedly set out an argument about the link between visa liberalization process and empowerment of pro-Russian forces. In February 2016, with reference to the expectedly forthcoming visa free-regime with the EU, he stated that "any failure in the direction of the European agenda will be used by those forces that are rather pro-Russian" (BBC Monitoring Trans Caucasus Unit 2014). Successively, in full electoral campaign, he bluntly pointed out that "[the] introduction of visa free travel for the Georgian nationals carries particular significance (..) For the purpose of instigating pro-Western aspirations within the Georgian society, tangible result shall be achieved prior to elections scheduled on October 8." According to this interpretation, such a prompt timing was necessary "in terms of encouraging pro-western aspirations and prevention of abuse of this temporary delay by anti-European forces" (Government of Georgia 2016). Similarly, President Margvelashvili reminded that the outcome of the Warsaw Summit ad of the Visa liberalization process were likely to have an impact on the highlypolarized forthcoming elections (President of Georgia 2016). Some other analysts and diplomats made comments in line with that, observing that the repeated postponing of the visa-free regime had favored pro-Russian parties. According to them, if previously pro-Russian stances had been akin a political suicide, now the message about the unreliability of the Western ally was gaining traction (Sputnik International 2016). On this topic, Bakur Kvashilava declared that, while a quick process of visa liberalization would represent a victory for the government, further delays could strengthen the narrative, proposed by "neutral parties," about the equal unreliability of Russia and the West. In this regard, Archil Karaulashvili, previously first deputy minister of Euro-Atlantic integration, observed that Moldova, ${ }^{30}$ although no more advanced than Georgia, was on a visa free free-regime. In consideration of the setback that this could have on ordinary citizens, he speculated that this visible disparity could be fertile terrain for Russian propaganda (Yerepouni Daily News 2015).

Notwithstanding the validity of these considerations, other elements suggested that, even if there were further delays, the effect on the electorate might not be that clear-cut. Although the timing of visa liberalization and the resurgence of pro-Russian political parties could be somehow related, ${ }^{31}$ the political narrative tends to exaggerate the importance of this factor. Notably, although "neutral politicians," such as Nino Burjanadze, ${ }^{32}$ have spoken of the perils of joining NATO, no comparable attention has been paid to the visa-free regime delays. Before the 2016 parliamentary elections, under the condition of anonymity, diplomatic sources agree that whatever the visa-liberalization outcome, it would have a limited impact on the behavior of the electorate. This is probably because, since a visa-free regime does not represent a step toward EU membership, campaigning over this issue would easily expose its weaknesses.

In light of these elements, it can be argued that the causal importance attributed, by Georgian elites, to the visa free-regime does not find perfect correspondence in the actual political landscape. Trying to attribute a meaning to that, this work considers that this emphasis on visa liberalization could be explained as an attempt to remind to Brussels that, in the absence of concrete benefits, the unbiased pro-Western orientation of the country could be reviewed. Although that choice is not ascribed to the ruling party, neutral parties are strategically described as potential spoilers, well above their actual potential, while visa liberalization is not only framed as a goal of Georgia but also as a useful tool to "keep the country on track."

\footnotetext{
${ }^{30}$ The expert and the political community is well aware that this difference is not due to arbitrary double standards but rather due to the earlier start of the Moldovan process. With reference to that, the Georgia parliament speaker Davit Usupashvili said, "We are little bit behind, but we are not jealous, we need to complete our homework and I believe in one year or so we will be able to complete that process as well" (Civil.ge 2014). However, in the grassroots Georgian perception, Moldova is not perceived as more advanced than Georgia (Interview to Bakur Kvashilava, Tbilisi, September 30, 2016).

${ }^{31}$ In October 2016, "Alliance of Patriots" was the only "neutral party" to pass the 5\% threshold and entered into parliament. In the weeks before the elections, the anti-Western rhetoric was considerably mitigated.

${ }^{32}$ Not elected in the parliamentary election of October 2016.
} 


\section{Conclusion}

This article, which gives at micro-meso-macro contribution, offers original insights on the case of Georgia, on visa policy, and on small states. It also sheds light on the evolving discourse on visa liberalization in Georgia. What emerges is a longstanding contradiction between being selfportrayed as a proud European country and the travel restrictions experienced for years by Georgian nationals. Additionally, some elements of continuity and departure in the use of the political rhetoric emerge. Further studies could compare these findings to the experience of other Eastern Partnership countries, such as Ukraine and Moldova. Regarding travel regimes, the Georgian experience fits into the categories reviewed by the relevant literature. More precisely, the Georgian attitude toward visa regimes could be interpreted both as a case of signaling openness and as the search for national status. In addition, it emerges how visa policies and discourses can be relevant both at the domestic and international levels. For example, the narrative on the visa-free regime promoting territorial reintegration seems to target both an external audience, namely EU decision-makers and diplomat, and an internal audience, namely those pro-Russian segments active in the Georgian political environment. Regarding small states, this work buys the assumption that there is some clear asymmetry between them and their greater external counter-parts. Building from that, it shows how small states can try to navigate this uneven relationship also by means of their political rhetoric, which can adjust over time to international opportunities and constraints. Going beyond the case study under analysis, this research could prompt further studies on small states' strategic agency.

Acknowledgments. The author thanks Professor John Doyle for his support throughout the years.

Financial Support. This research was supported by a Marie Curie Initial Training Network within the 7th European Community Framework Programme Grant number 316825.

Author ORCID. iD Chiara Loda, https://orcid.org/0000-0002-0075-9063

\section{References}

Ademmer, Esther and Tanja A. Börzel. 2013. “Migration, Energy and Good Governance in the EU's Eastern Neighbourhood." Europe-Asia Studies 65 (4): 581-608.

Ademmer, Esther and Laure Delcour. 2016. "With a Little Help from Russia? The European Union and Visa Liberalisation with Post-Soviet States." Eurasian Geography and Economics 57 (1): 89-112.

Ademmer, Esther. 2012. "The Process of Visa Facilitation in the European Neighbourhood-A Tool in Need of Refinement." In Policy Change in the EU's Immediate Neighbourhood: A Sectoral Approach, edited by Tanja A. Börzel and Katrin Böttger. Berlin, Germany: Nomos.

Agence France Presse. 2005. “Georgia Allows Visa-Free Travel from 30 Countries.” June 2.

Agenda.ge. 2015. “Check If You Can Enter Georgia and Stay for a Year Visa-Free.” June 10. http://agenda.ge/news/36828/ eng.

AP Worldstream. 2005. “Georgia Scraps Visa Requirement for Citizens from EU, US and Other Western Countries.” June 2. Aydın-Düzgit, Senem. 2016. "De-Europeanisation through Discourse: A Critical Discourse Analysis of AKP's Election Speeches." South European Society and Politics 21 (1): 45-58.

BBC Monitoring Former Soviet Union. 2005. "Russian Ministry Confirms 80 Percent of Abkhazians Are Russian Citizens." August 19.

BBC Monitoring Former Soviet Union. 2006. “Georgian President Praises Ties with Turkey.” December 20.

BBC Monitoring Former Soviet Union. 2013. Russian Commentary Says EU Deals to Trigger Disintegration of Georgia, Moldova. December 13.

BBC Monitoring Trans Caucasus Unit. 2014. "Georgian PM Urges Strong Public Support for European Aspirations.” February 14.

BBC Monitoring Trans Caucasus Unit. 2016a. "Georgia PM Talks EU Visa Liberalisation, Elections and Economic Growth in Prague." February 23.

BBC Monitoring Trans Caucasus Unit. 2016b. "Georgian Minister Praises Results of State Policy on Breakaway Abkhazia, Ossetia." March 9.

BBC Monitoring Trans Caucasus Unit. 2014. "Georgian PM Urges Strong Public Support for European Aspirations." February 14. 
Bertrand, Natasha. 2015. "Russia Just Dealt a Huge Blow to Turkey over Its Downing of a Russian Warplane.” Business Insider UK, November 27.

Börzel, Tanja A. 2016. "Building Member States: How the EU Promotes Political Change in Its New Members, Accession Candidates, and Eastern Neighbors." Geopolitics, History and International Relations 8 (1): 76-112.

Brisku, Adrian. 2013. Bittersweet Europe: Albanian and Georgian discourses on Europe, 1878-2008. New York: Berghahn Books.

Cagara, Dominik K. 2015. “Tbilisi super cup heats up an old debate in Abkhazia.” Democracy and Freedom Watch, August 25. http://dfwatch.net/tbilisi-super-cup-heats-up-an-old-debate-in-abkhazia-37981.

Caspersen, Nina. 2015. “The Pursuit of International Recognition After Kosovo." Global Governance: A Review of Multilateralism and International Organizations 21 (3): 393-412.

Chang, Ha-Joon. 2007. Bad Samaritans: The Myth of Free Trade and the Secret History of Capitalism. New York: Bloomsbury Publishing USA.

Cheterian, Vicken. 2008. "Georgia's Rose Revolution: Change or Repetition? Tension between State-Building and Modernization Projects.” Nationalities Papers 36 (4): 689-712.

Civil.ge. 2014. "Parliament Speaker Visits Moldova," April 29. http://www.civil.ge/eng/article.php?id=27179.

CRRC. 2016. "NDI: Public Attitudes in Georgia, June 2016." The Caucasus Research Resource Centers. http:// caucasusbarometer.org/en/nj2016ge/VISABEN/.

CRRC. 2015. "Knowledge and attitudes toward the EU in Georgia, 2015." The Caucasus Research Resource Centers. http:// caucasusbarometer.org/en/eu2015ge/codebook/.

De Waal, Thomas. 2011. Georgia's Choices Charting a Future in Uncertain Times. Washington, DC: Carnegie Endowment for International Peace.

Delcour, Laure. 2013. "Meandering Europeanisation: EU Policy Instruments and Policy Convergence in Georgia under the Eastern Partnership.” East European Politics 29 (3): 344-357.

Delcour, Laure and Kataryna Wolczuk. 2015. “The EU's Unexpected 'Ideal Neighbour'? The Perplexing Case of Armenia's Europeanisation.” Journal of European Integration 37 (4): 1-17.

Devrim, Deniz and Eduard Soler. 2010. “Turkey's Bold New Visa Diplomacy.” Notes Internationals. Barcelona, Spain: CIDOB.

Ellena, Monica. 2015. “Georgia's new migration policy: raising barriers or improving regulations?” Financial Times, March 26. https://www.ft.com/content/42afc5c9-08a4-3fc5-b8c6-b85a4e78d674.

European Commission. 2015. “Commission Progress Report: Georgia Meets Criteria for Visa Liberalization.” December 18. http://europa.eu/rapid/press-release_IP-15-6368_en.htm. (Accessed on April 10, 2017.)

European Union External Action. 2015. "Statement by High Representative/Vice-President Federica Mogherini on the Announced Signature of a "Treaty on Alliance and Integration" between the Russian Federation and Georgia's Breakaway Region of South Ossetia,” Brussels, March 17. http://collections.internetmemory.org/haeu/content/20160313172652/ http://eeas.europa.eu/statements-eeas/2015/150317_04_en.htm.

Finotelli, Claudia and Giuseppe Sciortino. 2013. “Through the Gates of the Fortress: European Visa Policies and the Limits of Immigration Control." Perspectives on European Politics and Society 14 (1): 80-101.

Gabrichidze, Gaga. 2011. "Development of Visa Policy in Georgia: In the Name of Liberalization?" CARIM East Consortium for Applied Research on International Migration. European University Institute. Warsaw, October 27-28. http://www.carim-east.eu/media/Gabrichidze.pdf.

German, Tracy. 2015. "Heading West? Georgia’s Euro-Atlantic Path.” International Affairs 91 (3): 601-614.

Golunov, Sergey. 2011. "EU-Russia Visa Talks: Open and Hidden Agendas.” PONARS Eurasia Policy Memo 144, May. http:// www.ponarseurasia.org/sites/default/files/policy-memos-pdf/pepm_144.pdf.

Government of Georgia. 2016. "Prime Minister at the Discussion Panel." September 6. http://gov.ge/index.php? lang_id=ENG\&sec_id=440\&info_id=57669.

Grant, Charles. 2011. "A New Neighbourhood Policy for the EU." Centre for European Reform Policy Brief.

Grigalashvili, Mariam. 2016. “The EU’s Visa Suspension Mechanism Explained.” Georgian Institute of Politics, December 13. http://gip.ge/the-eus-visa-suspension-mechanism-explained/. (Accessed on April 10, 2017.)

Helleiner, Jane. 2015. "Recruiting the 'Culturally Compatible' Migrant: Irish Working Holiday Migration and White Settler Canadianness.” Ethnicities 17 (3): 1-21.

Irish Statute Book. 2017. S.I. No. 264/2017-Immigration Act 2004 (Visas) (Amendment) Order 2017, June 16. http://www. irishstatutebook.ie/eli/2017/si/264/made/en/pdf. (Accessed July 1, 2017.)

Jansen, Stef. 2009. “After the Red Passport: Towards an Anthropology of the Everyday Geopolitics of Entrapment in the EU's 'Immediate Outside." Journal of the Royal Anthropological Institute 15 (4): 815-832.

Kakachia, Kornely, and Salome Minesashvili. 2015. "Identity Politics: Exploring Georgian Foreign Policy Behavior." Journal of Eurasian Studies 6 (2): 171-180.

Kakhishvili, Levan. 2016. "Georgia-the Choice: The Perceived West-Russia Dichotomy in Georgian Politics." In Caucasus, the EU and Russia-Triangular Cooperation?, edited by Michèle Knodt and Sigita Urdze, 165-188. Baden-Baden, Germany: Nomos Verlagsgesellschaft mbH \& Co. KG. 
Kirişçi, Kemal, and Neslihan Kaptanoğlu. 2011. “The Politics of Trade and Turkish Foreign Policy.” Middle Eastern Studies 47 (5): 705-724.

Kirisci, Kemal. 2005. “A Friendlier Schengen Visa System as a Tool of 'Soft Power”: The Experience of Turkey.” European Journal of Migration and Law 7 (4): 343-367.

Lazarus, Joel. 2013. "Democracy or Good Governance? Globalisation, Transnational Capital, and Georgia's Neo-liberal Revolution." Journal of Intervention and Statebuilding 7 (3): 259-286.

Loda, Chiara. 2016. "Azerbaijan, Foreign Policy and Public Diplomacy.” Irish Studies in International Affairs 27: 39-55.

Loda, Chiara. 2017. Strategic Narratives as Public Diplomacy? The Case of Armenia. Tensions Policy Paper, March 1. http:// postsoviet.eu/2017/03/01/strategic-narratives-as-public-diplomacy-the-case-of-armenia/.

Margvelashvili, Giorgi. 2013. Address of the President of Georgia Eastern Partnership Summit. President of Georgia, November 28. https://www.president.gov.ge/en-US/pressamsakhuri/siakhleebi/Address-of-the-President-of-Georgia-Eastern-Pa-(1).aspx.

Margvelashvili, Giorgi. 2016. “The President of Georgia Met Mr Donald Tusk in Washington.” President of Georgia. April 2. https://www.president.gov.ge/en/PressOffice/News/Releases?p=10187\&i=3.

Mau, Steffen, Fabian Gülzau, Lena Laube, and Natascha Zaun. 2015. “The Global Mobility Divide: How Visa Policies Have Evolved over Time.” Journal of Ethnic and Migration Studies 41 (8): 1192-1213.

Mau, Steffen. 2010. "Mobility Citizenship, Inequality, and the Liberal State: The Case of Visa Policies." International Political Sociology 4 (4): 339-361.

Menabde, Giorgi. 2015. "Why Are Ossetians and Abkhazians Coming to Georgia for Medical Treatment?" Eurasia Daily Monitor 12 (43), The Jamestown Foundation, March 9.

Minesashvili, Salome and Levan Kakhishvili. 2015. "Georgia: Foreign Policy Identity in the Domestic Arena as a Subject of Contestation." In Identity, Norms and Beliefs in Foreign Policy, edited by Kornely K. Kakachia, Caucasus Analytical Digest 77, September 14.

Mirzoyan, Alla. 2010. Armenia, the Regional Powers, and the West: Between History and Geopolitics. New York: Palgrave Macmillan.

Moody, Claire. 2016. “Georgia's EU Visa Waiver Should Not Be Politicised.” EUObserver, Brussels, September 5.

Neumayer, Eric. 2006. "Unequal Access to Foreign Spaces: How States Use Visa Restrictions to Regulate Mobility in a Globalized World." Transactions of the Institute of British Geographers 31 (1): 72-84.

Neumayer, Eric. 2010. "Visa Restrictions and Bilateral Travel." The Professional Geographer 62 (2): 171-181.

Ó Beacháin, Donnacha, and Frederik Coene. 2014. "Go West: Georgia’s European Identity and Its Role in Domestic Politics and Foreign Policy Objectives." Nationalities Papers 42 (6): 923-941.

Öner, Selcen. 2013. "Soft Power in Turkish Foreign Policy: New Instruments and Challenges." Euxeinos: Governance and Culture in the Black Sea Region 10: 7-15.

Özler, Zeynep. 2012. “Breaking Vicious Circle in EU-Turkey Relations: Visa Negotiations.” Turkish Policy Quarterly 11 (1): 121-131.

Papava, Vladimer. 2013. “Economic Achievements of Postrevolutionary Georgia: Myths and Reality.” Problems of Economic Transition 56 (2): 51-65.

Papava, Vladimer. 2014. "Georgia's Economy: The Search for a Development Model." Problems of Economic Transition 57 (3): 83-94.

Papidze, Mariam. 2017. "How I Entered EU Without Visa.” Agenda.ge, March 31.

Paul, T. V. and Mahesh Shankar. 2014. "Status Accommodation through Institutional Means: India's Rise and the Global Order." In Status in World Politics, edited by T.V. Paul, Deborah Welch Larson, and William C. Wohlforth, 165-191. Cambridge, UK: Cambridge University Press.

Popescu, Nicu and Andrew Wilson. 2009. The Limits of Enlargement-lite: European and Russian Power in the Troubled Neighbourhood. European Council of Foreign Relations.

Pomfret, Richard. 2008. "Turkmenistan after Turkmenbashi” (No. 2008/03). PFH Forschungspapiere/Research Papers 2008/ 03. Göttingen, Germany: Private University of Applied Sciences.

President of Georgia. 2005. "President Mikheil Saakashvili Attends Old Tbilisi Rehabilitation Project Presentation." May 25.

President of Georgia. 2015. "President of Georgia Meets with the High Representative of the European Union for Foreign Affairs and Security Policy Federica Mogherini." News, November 11.

President of Georgia. 2016. "The President H.E. Giorgi Margvelashvili: Our Challenge in this Election Is to Bring Citizens to the Voting Booth,” June 7. https://www.president.gov.ge/en/PressOffice/News? 10377.

Saakashvili, Mikheil. 2005a. Speech. May 26, President of Georgia.

Saakashvili, Mikheil. 2006a. Speech. February 18, President of Georgia.

Saakashvili, Mikheil. 2006b. Speech. March 14, President of Georgia.

Saakashvili, Mikheil. 2006c. Speech. July 13, President of Georgia.

Saakashvili, Mikheil. 2006d. Speech. April 17, President of Georgia.

Saakashvili, Mikheil. 2007a. Speech. February 3, President of Georgia.

Saakashvili, Mikheil. 2009a. Speech. March 22, President of Georgia. 
Saakashvili, Mikheil. 2009b. Speech. November 13, President of Georgia.

Saakashvili, Mikheil. 2010. Speech. March 3, President of Georgia.

Sagan, Scott. 1996. "Why Do States Build Nuclear Weapons? Three Models in Search of a Bomb." International Security 21 (3): 54-86.

Salter, Mark B. 2006. “The Global Visa Regime and the Political Technologies of the International Self: Borders, Bodies, Biopolitics." Alternatives 31 (2): 167-189.

Sasse, Gwendolyn. 2016. "Ukraine's Visa Liberalization Saga.” Judy Dempsey's Strategic Europe, Carnagie Europe. November 28, http://carnegieeurope.eu/strategiceurope/66262 (Accessed on July 2, 2017).

Sasse, Gwendolyn. 2017. “Ukrainians Travel Visa Free.” Judy Dempsey’s Strategic Europe, Carnagie Europe. June 26, http:// carnegieeurope.eu/strategiceurope/71354 (Accessed on July 2, 2017).

Sputnik International. 2016. "Waking From the European Dream, Georgians Pondering Pivot Back to Russia." July 19.

Steinmetz, Robert and Wivel, Anders. 2010. "Introduction.” In Small States in Europe: Challenges and Opportunities, Edited by Robert Steinmetz and Anders Wivel, 3-14. Farnham, UK: Ashgate.

Tabula. 2014. "Georgia Abolishes Visa Free Regime for 24 Countries," August 26, http://www.tabula.ge/en/story/87085georgia-abolishes-visa-free-regime-for-24-countries\#comments.

Tsuladze, Lia, Flora Esebua, Irakli Kakhidze, Ana Kvintradze, Irina Osepashvili, and Mariam Amashukeli. 2016. Performing Europeanization-Political vis-à-vis Popular Discourses on Europeanization in Georgia. Tbilisi: Nekeri.

Tsurtsumia-Zurabashvili, Ann. 2016. "Visa-Free Travel to the European Union: Prospects for a European Choice and Democratization by the Occupied Territories of Georgia." Georgian Institute of Politics, May.

Umodov, Agshin. 2010. "Why Does Georgia’s Visa-Free Regime in the North Caucasus Concern Russia?” USAK, Caucasia Analysis, October 22.

Wilson, Andrew and Nicu Popescu. 2009. "Russian and European Neighbourhood Policies Compared." Southeast European and Black Sea Studies 9 (3): 317-331.

Wivel, Anders. 2016. "Living on the Edge: Georgian Foreign Policy between the West and the Rest." Third World Thematics: A TWQ Journal 1 (1): 92-109.

Yerepouni Daily News. 2015. “Left Dangling by EU, Some Georgians Eye Return to Russia’s Embrace.” June 18.

Yundt, Heather. 2014. "Georgia Ends Immigration Free-for-All." Institute for War \& Peace Reporting. Global Voices Caucasus, September 29. https://iwpr.net/global-voices/georgia-ends-immigration-free-all.

Cite this article: Loda, C. 2019. Georgia, the European Union, and the Visa-Free Travel Regime: Between European Identity and Strategic Pragmatism. Nationalities Papers 47: 72-86, doi:10.1017/nps.2018.7 